СМУ-9.

\title{
ВОЗМОЖНОСТИ АТОМНО-АБСОРБЦИОННОЙ СПЕКТРОМЕТРИИ С ДВУХСТАДИЙНОЙ ЗОНДОВОЙ ЭЛЕКТРОТЕРМИЧЕСКОЙ АТОМИЗАЦИЕЙ
}

\author{
Волженин А. В. ${ }^{1}$, Петрова Н. И. ${ }^{1}$, Медведев Н.С. ${ }^{1}$, Сапрыкин А. И. ${ }^{1,2}$
}

${ }^{1}$ ФГБУН Институт неорганической химии им. А.В. Николаева СО РАН, Новосибирск, Россия

${ }^{2}$ Новосибирский национальный исследовательский государственный университет, Новосибирск, Россия

volzhenin@niic.nsc.ru

DOI: 10.26902/ASFE-11_89

Определение содержания благородных металлов (БМ) в различных объектах остается актуальной задачей. Необходимый уровень определения $\left(10^{-6}\right.$ мас.\%), является достижимым для атомно-абсорбционной спектрометрии с электротермической атомизацией (ААС-ЭТА), однако наличие мешающих матричных компонентов и неоднородность геологических объектов ограничивают возможности метода. Для количественного ААС-ЭТА определения БМ в породах и рудах необходимо полное разложение проб, отделение матричных компонентов и концентрирование, что занимает много времени и увеличивает риск внесения загрязнений.

Ранее было показано $[1,2]$, что можно исключить или значительно снизить матричные помехи в ААС-ЭТА при определении золота и палладия в горных породах и рудах благодаря применению специальной приставки АТЗОНД-1 для двухстадийной зондовой атомизации (ДЗА) и способа пробоподготовки, состоящего из кратковременного разложения царской водкой с последующим разбавлением водой и анализом полученной суспензии. В настоящей работе нами изучена возможность многократного концентрирования $\mathrm{Au}$ и $\mathrm{Pd}$ на зонде с последующим определением методом ААС-ЭТА с ДЗА. Показано, что повторение стадий улавливания аналитов на вольфрамовый зонд приводит к росту аналитического сигнала, частично компенсируя неполное улавливание (в ходе единичного улавливания на зонд улавливается до 35\% золота и до 20\% палладия, находящихся в аликвоте). Установлено оптимальное число циклов улавливания для получения максимального сигнала при введении геологических объектов в электротермический атомизатор, оптимизирована температурновременная программа. Правильность методик подтверждена анализом ГСО горных пород и руд: РМО-5, С3Х-3, СОП-2-90. Содержание аналитов определяли с использованием метода добавок. Благодаря многократному улавливанию (концентрированию) пределы обнаружения БМ в горных породах, рудах и отходах электротехнической промышленности были снижены в 5-6 раз по сравнению с пределами обнаружения, полученными ранее для способа ДЗА-ЭТА$\mathrm{AAC}$, и составили 0,0025 и 0,007 г/т для $\mathrm{Au}$ и $\mathrm{Pd}$, соответственно. Полученные в данной работе результаты позволяют расширить диапазон определения золота и палладия в различных объектах.

\section{Список литературы}

1. Захаров Ю.А., Окунев Р.В., Хасанова С.И., Ирисов Д.С., Хайбуллин Р.Р. //Аналитика и контроль. 2013. № 4 . C.414.

2. А.В. Волженин, Н.И. Петрова, Н.С. Медведев, Д.С. Ирисов, А.И. Сапрыкин. // Журнал аналитической химии. 2017. т. 72. № 2. с. 129-136.

Работа выполнена в рамках государственного задания ИНХ СО РАН в области фундаментальных научных исследований, проект № 121031700315-2. 